\title{
Effects of Quercetin on the Green Hydra (Hydra viridissima Pallas, 1766)
}

\author{
Goran Kovačević ${ }^{1} \&$ Ana Matulić ${ }^{2}$ \\ ${ }^{1}$ Department of Zoology, Faculty of Science, University of Zagreb, Zagreb, Croatia \\ ${ }^{2}$ Elementary school Dubrava, Dubrava, Croatia \\ Correspondence: Goran Kovačević, Division of Biology, Department of Zoology, Faculty of Science, University \\ of Zagreb, Rooseveltov trg 6, Zagreb HR-10000, Croatia. Tel: 38-516-189-702. E-mail: \\ goran.kovacevic@biol.pmf.hr
}

Received: March 18, 2013 Accepted: May 10, 2013 Online Published: May 21, 2013

doi:10.5539/ijb.v5n3p57 URL: http://dx.doi.org/10.5539/ijb.v5n3p57

\begin{abstract}
Effects of quercetin on the green hydra, Hydra viridissima Pallas, and its endosymbiotic alga were studied under laboratory conditions. Quercetin is the most studied flavonoid known for its ability to act as an antioxidant, but it can also show a pro-oxidative effect. Green hydras were treated with four concentrations of quercetin $(0.12 \mathrm{~g} / \mathrm{L}$, $0.2 \mathrm{~g} / \mathrm{L}, 0.25 \mathrm{~g} / \mathrm{L}$ and $0.3 \mathrm{~g} / \mathrm{L}$ ) for three days and compared to the control group of animals. Through the use of light microscopy, morphometry and macroscopic observations the results showed morphological changes in the hydra body as well as behavioral changes: depigmentation, migration, deformation, disordered locomotion, diminished reactions to mechanical stimuli and mortality. Further, different histopathological changes in the hydra body were detected. Different changes were monitored in the endosymbiotic alga: cell viability, division, shape and size of cells and chloroplasts, the level of damage and intensity of green color. Based on our results, the most important conclusion is that quercetin has a possible pro-oxidative effect on the green hydra.
\end{abstract}

Keywords: green hydra, endosymbiotic alga, quercetin, toxicity, morphological and histological changes, morphometry

\section{Introduction}

Quercetin (3,3',4',5,7-pentahydroxyflavone) is a unique bioflavonoid that has been extensively studied over the past 30 years. Flavonoids belong to a group of organic compounds with phenolic structure. They are natural compounds that are found in different fruits and vegetables, cereals, flowers, tea and wine. More than 8,000 various flavonoids have been detected so far and they can be divided into various groups: anthocyanins, flavonols, flavanons, flavones, isoflavones, catehines, calcones and aurones (Cotelle, 2001). Flavonoids have anti-bacterial, anti-carcinogenic and anti-inflammatory effects and their beneficiary effect on health was known much earlier than they were isolated as active compounds (De Groot \& Rauen, 1998). The best-described property of quercetin is its ability to act as antioxidant. Quercetin seems to be the most powerful flavonoid, protecting the body against reactive oxygen species (ROS), produced during the normal oxygen metabolism or induced by exogenous impact (De Groot, 1994; Grace, 1994). There is a lot of controversy regarding the possible toxic or even mutagenic properties of quercetin and toxic effect of quercetin was noted under in vitro conditions (Formica \& Regelson, 1995). Lower concentrations of quercetin can stimulate proliferation of some cancer cells that depend on estrogen receptors. Higher concentrations of quercetin may have cytotoxic effect on the same cells (Maggiolini et al., 2001). Quercetin can be antioxidant or pro-oxidant, depending on the concentration and source of free radicals in a cell (Lee, Kim, Park, Chung, \& Jang, 2003).

Symbiotic associations are of wide significance in evolution, providing biological advantages and contributing to biological diversity. Some flavonoids are necessary for symbiotic associations of plants and bacteria, having the role of signal molecules. Flavonoids can also have stimulating or inhibiting effect on micorrhyza formation (Baker, 1995). Endosymbiosis is a form of symbiosis in which at least two genomes of different evolutionary origin exist within the same cytoplasm (Ebringer \& Krajčovič, 1994). Hydras are aquatic cosmopolitan invertebrates that belong to the phylum Cnidaria (Hydrozoa, Hydroida) (Holstein \& Emeschermann, 1995), and exhibit great regeneration ability. The body of the hydra comprises of three regions - hypostome with tentacles that contain cnidae, body with budding region, and foot with a basal disc. Three layers build the body of hydra: 
outer ectodermal cellular, mesoglea located between the two cellular layers and inner gastrodermal cellular layer, which surrounds the gastrovascular cavity. The green hydra (Hydra viridissima Pallas, 1766) represents a typical endosymbiotic organism. This species contains unicellular endosymbiotic algae in its gastrodermal myoepithelial cells, each alga in one symbiosome, surrounded by perialgal space. Up to 20 individuals of green algae can be found in one cell (Holstein \& Emschermann, 1995). It is belived that hydra can be a suitable experimental animal for establishing the lethal and sublethal doses of toxicants as well as explaining the effects of pollutants on freshwater systems (Arkhipchuk, Blaise, \& Malinovskaya, 2005; Beach \& Pascoe, 1998; Kalafatić \& Kopjar, 1994; Kovačević, Kalafatić, Ljubešić, \& Šunjić, 2001).

Morphometry is a scientific method which comprises quantitative measurements of diverse morphological structures of organisms, organs, tissues, individual cells, organelles and is used in biology as well as biomedicine (Agosttinucci et al., 2002). Morphometry was used as an analytical tool in our research in addition to other quantitative and qualitative techniques.

Since quercetin shows both stimulating and inhibiting effects on organisms, it is interesting to observe its effects on the green hydra, which exhibits great regeneration ability. The purpose of this study was to investigate the qualitative and quantitative changes in the green hydra and their endosymbiotic alga in response to different dosages of quercetin.

\section{Materials and Methods}

Individuals of green hydra (Hydra viridissima Pallas, 1766) were kept in the laboratory in aerated aquarium water. Hydras were fed with nauplia of Artemia salina two times a week. Four days before the experiment and during the experiment hydras were not fed. Undamaged individuals without buds, uniformly sized and of equally developmental stage were chosen for the experiment. Hydras were treated with four concentrations of quercetin: $0.12 \mathrm{~g} / \mathrm{L}, 0.2 \mathrm{~g} / \mathrm{L}, 0.25 \mathrm{~g} / \mathrm{L}$ and $0.3 \mathrm{~g} / \mathrm{L}$ for 72 hours $\left(50 \mathrm{~mL}\right.$ each), according to ca. $\mathrm{LC}_{50}$ at $0.3 \mathrm{~g} / \mathrm{L}$ of quercetin. Quercetin was dissolved in aerated water. In each group of treated hydras as well as in the control group 10 hydras were used. One group served as control in aerated water. Hydras were kept in water solutions of quercetin for 72 hours at the room temperature $\left(28^{\circ} \mathrm{C}\right)$, in glass dishes. Static toxicity test was used. The experiment was performed in triplicate during the year 2012 at the Division of Biology, Faculty of Science, Zagreb.

Morphological and locomotory changes were observed by stereolupe and recorded every 24 hours during three days. Morphological, locomotory and behavioral changes of green hydra were studied. Viability, mortality, deformations, depigmentation, mucous production, tentacle reduction and migrations of hydras and possible pro-oxidative effect of quercetin were traced.

Cyto-histological changes of three hydra layers were also evaluated as well as changes of endosymbiotic algae including: viability, shape and size of cells, level of damage, fragmentation of chloroplasts and intensity of green color in relation to the concentration of the toxicant. For histological analysis standard preparation methods and hydras from the three highest concentrations were used. Samples were dyed with Meyer's solution as well as toluidine blue. Changes on endosymbiotic algae were monitored 72 hours after the beginning of the experiment and particular preparations were made by maceration of two hydras from each concentration as well as from control. For morphometrical analysis software program Lucia G 4.80 was used, and micrographs were made by digital camera Nikon DXM 1200.

For morphometric analysis area and diameter of algae were measured on the sample of 100 cells, and area of chloroplasts was measured on a sample of 50 cells. Thickness of mesoglea was measured on histological preparations of hydras in 100 randomly chosen places.

Descriptive statistics were preformed using Microsoft Office Excel 2007. All parameters studied were presented as average value and standard deviation. Statistical significance between the control and the treated groups as well between the treated groups themselves were evaluated by the use of t-test (STATISTICA 7.1). The level of significance was set at $\mathrm{p} \leq 0.05$.

\section{Results and Discussion}

Quercetin caused morphological and cyto-histological changes in the green hydra. During the experiment higher concentrations caused more intensive changes. The overview of the results is given in the Figures 1-4 and Tables $1-4$.

Morphological changes comprised of different parameters. Higher migration rate occurred during the treatment where individuals of the green hydra migrated to the surface and also showed more inhibited reactions to the mechanical stimuli, as a result of unfavorable and deleterious micro-environmental conditions (Kovačević, Želježić, Kalafatić, \& Horvatin, 2007). Quercetin also caused up to or over $50 \%$ of disordered locomotion, 
deformation and intensive production of mucous (Kalafatić, Kovačević, Ljubešić, \& Šunjić, 2001). Production of large quantities of mucous is the result of damage to ectodermal myoepithelial cells, which are capable of secretion activity (Kalafatić, 1995), and this secretion of mucous could represent a mechanism for detoxication (Kovačević, Gregorović, Kalafatić, \& Jaklinović, 2009). Mucous layer protects from unfavorable environmental conditions (Burnett, 1973) and increased mucous secretion is noted during treatment of invertebrates with aluminum or other metals (Wilson, Bergman, \& Wood, 1994). Damages to the mucous layer, and subsequently to the ectoderm, facilitate the entrance of the toxicant. Moreover, individuals of green hydra with depigmentation of the basal part and spotted green coloration were recorded, pointing out the changes in the endosymbiont, e.g. degradation and damage. Damage to the tentacles was visible as their reduction, exceeding $80 \%$, in response to particular concentrations of quercetin. Most of the tentacles were shortened and some even were severed to the base. Relaxed tentacles were noted in the control as well as in the treatment (Table 1), which could be in response to the high temperature and lowered oxygen concentration.

Quercetin caused mortality of hydras at the three highest concentrations and the mortality was dose-dependent (Table 2). It is known that depending on the dose some xenobiotics can cause changes in behavior, morphology and cellular structures (Kalafatić et al., 2001). At the lowest concentration hydras started to show light changes, and in the next higher concentration more intensive sub-lethal changes occurred and the onset of the irreversible effect of quercetin resulted in mortality. At concentrations above $0.3 \mathrm{mg} / \mathrm{L}$ of quercetin (data not shown) mortality occurred at a very fast rate. Recently, the effect of quercetin has been also studied on planarians and mice (Rajević, Matković, Gregorović, Kovačević, Knezović, \& Kalafatić, 2013; Sirovina, Oršolić, Končić, Kovačević, Benković, \& Gregorović, 2013).

Table 1. Morphological changes (\%) of hydras in response to treatments with different concentrations of quercetin

\begin{tabular}{|c|c|c|c|c|c|c|c|c|c|}
\hline $\begin{array}{l}\text { Concentration } \\
\text { of } \\
\text { quercetin } / \mathrm{g} / \mathrm{L}\end{array}$ & Migration & $\begin{array}{l}\text { Mucous } \\
\text { production }\end{array}$ & $\begin{array}{l}\text { Foot } \\
\text { deformations }\end{array}$ & $\begin{array}{l}\text { Tentacle } \\
\text { reduction }\end{array}$ & $\begin{array}{l}\text { Relaxed } \\
\text { tentacles }\end{array}$ & Depigmentations & $\begin{array}{l}\text { Inhibited } \\
\text { reaction to } \\
\text { the } \\
\text { mechanical } \\
\text { stimuli }\end{array}$ & $\begin{array}{l}\text { Disordered } \\
\text { locomotion }\end{array}$ & $\begin{array}{l}\text { Spotted } \\
\text { green } \\
\text { coloration }\end{array}$ \\
\hline $\mathrm{C}$ & 30 & 0 & 0 & 0 & 33.3 & 0 & 43.3 & 0 & 0 \\
\hline 0.2 & 33.3 & 50 & 53.3 & 86.6 & 0 & 33.3 & 93.3 & 40 & 50 \\
\hline 0.25 & 43.3 & 63.3 & 56.6 & 66.6 & 3.3 & 50 & 73.3 & 46.6 & 56.6 \\
\hline 0.3 & 43.3 & 53.3 & 60 & 70 & 6.6 & 50 & 46.6 & 46.6 & 43.3 \\
\hline
\end{tabular}

$\mathrm{C}-$ control.

Table 2. Mortality (\%) of hydras in response to treatments with different concentrations of quercetin

\begin{tabular}{llllll}
\hline Concentration of quercetin/g/L & $\mathrm{C}$ & 0.12 & 0.2 & 0.25 & 0.3 \\
\hline $1^{\text {st }}$ day & 0 & 0 & 0 & 0 & 0 \\
$2^{\text {nd }}$ day & 0 & 0 & 0 & 10 & 16.6 \\
$3^{\text {rd }}$ day & 0 & 0 & 10 & 6.6 & 30 \\
Total & 0 & 0 & 10 & 16.6 & 46.6 \\
\hline
\end{tabular}

$\mathrm{C}$ - control.

Cyto-histological changes comprised of damage to the ectoderm, mesoglea and gastroderm and changes in the position endosymbiotic algae. Control had regular cyto-histological structure with a smaller number of interstitial cells (I-cells) present in the ectoderm and no damage was noted. At a concentration of $0.2 \mathrm{~g} / \mathrm{L}$ of quercetin after 72 hours of treatment almost no damage in cyto-histological structure was noted. The only signs of damage were cnidae spread from the tentacles into the foot. Some zymogene cells were transformed into gastrodermal I-cells and a lot of I-cells were present in the ectoderm. Formation of ovaries on each side of the hydra body was noted, which implies an attempt at sexual reproduction as a result of unfavorable 
micro-environmental conditions. At concentration $0.25 \mathrm{~g} / \mathrm{L}$ of quercetin more intensive damage was present. Ectoderm was reduced and damaged with the I-cells present. Transformation of zymogene cells to interstitial cells migrating across mesoglea to regenerate ectoderm was also visible which implied the attempt of regeneration of damaged body parts (Kalafatić et al., 2001). Gastrodermal cells were of amorphous structure and thin mesoglea was reduced. At concentration $0.3 \mathrm{~g} / \mathrm{L}$ of quercetin most damage of the cyto-histological material was noted. Ectoderm was even more reduced and mostly no I-cells were present. Zymogene cells were also mostly not present, indicating that at this high concentration regeneration was no longer possible. Mesoglea was extremely reduced (Table 3). At the places where mesoglea is damaged or missing, migration of cells is possible (Breslin-Spangener \& Eakin, 1962.).

I-cells are the reserve of somatic embryonic elements capable of transformation and differentiation into other cell types. Zymogene cells contribute to growth and regeneration processes and are capable of differentiation and transformation into gastrodermal I-cells that participate in the regeneration of damaged body parts. In the gastroderm of treated hydras the change and position of zymogene cells was evident (Kalafatić \& Kopjar, 1994). In our study the gastroderm, as the inner cellular layer, was damaged, but to a smaller extent than the other layers. Cnidae fell out of the tentacles and spread all over the hydra body as did the endosymbiotic algae. In the control, cnidae are regularly situated in tentacles and algae in gastrodermal myoepithelial cells of green hydra (Pool \& Muscatine, 1980). Since the inner layer of the hydra was damaged, algae migrated into the foot and the hypostome (Table 3).

Table 3. Cyto-histological changes of hydras in response to treatments with different concentrations of quercetin

\begin{tabular}{rlllll}
\hline Concentration of quercetin/g/L & $\mathrm{C}$ & 0.2 & 0.25 & 0.3 \\
\cline { 2 - 5 } Regular organization of layers & +++ & +++ & ++ & + \\
Regular distribution of algae & +++ & ++ & + & 0 \\
Presence of zymogene cells & + & ++ & +++ & + \\
\hline C - control; ++ - intensively expressed; ++ - expressed; + - partially present; 0 - not present.
\end{tabular}

Intensive green color was noted by micro-observations of control endosymbionts, they divided into up to three cells and contained regular cup-like chloroplasts. These parameters changed with the higher concentration: the structure of chloroplasts became irregular and the intensity of green color decreased. In the highest concentration of quercetin, cells were yellow-like and only particular division attempts were observed. The proper structure of chloroplasts was best conserved in the lowest concentration and as the concentration of quercetin was increased the chloroplast structure was more damaged. At all concentrations chloroplasts had lower intensity of green color compared to the control, as a result of the degradation of plastids (Table 4). It is known that phytotoxicity changes the structure of chloroplasts. Pigment analysis in further experiments could explain this result in detail.

Divisions of endosymbiotic algae decreased with the higher concentration of quercetin. The proper round shape of the cells was best conserved at concentration of $0.25 \mathrm{~g} / \mathrm{L}$. At the highest concentration the shape of cells was mainly oval. Considering that the preparations were made by fresh maceration, once being out of the host cells, the endosymbiotic algal cells could change their shape in due course. Further research using an electron microscope could provide a more detailed explanation of the described changes.

Table 4. Morphological changes in freshly isolated endosymbiotic algae in response to different concentrations of quercetin

\begin{tabular}{|c|c|c|c|c|c|}
\hline Concentration of quercetin/g/L & $\mathrm{C}$ & 0.12 & 0.2 & 0.25 & 0.3 \\
\hline Regular structure of chloroplast & +++ & +++ & ++ & ++ & + \\
\hline Intensity of green color & +++ & ++ & ++ & ++ & + \\
\hline
\end{tabular}

The morphometric results nearly always showed a decrease in the cell area and diameter as well as in chloroplast area and thickness of mesoglea in the treated groups compared to the control (Figures 1-4). Further morphometric analysis, e.g. number of gastrodermal, I- and zymogene cells could give a detailed insight into the changes that were monitored. 


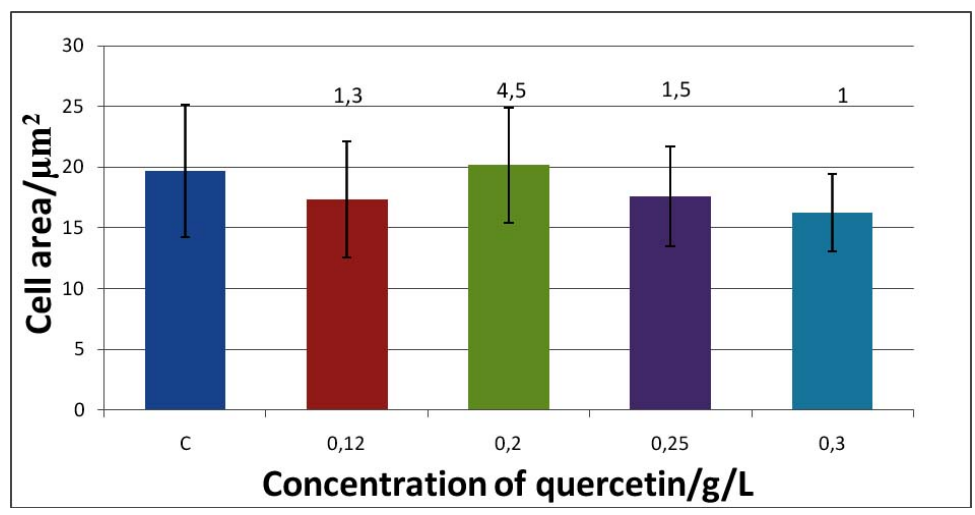

Figure 1. Relationship between the algal cell area and concentration of quercetin. Vertical lines represent standard deviation. $\mathrm{C}-$ control. Statistically significant $(\mathrm{p}<0.05): 1-$ in relation to $\mathrm{C}, 3-$ in relation to $0.2 \mathrm{~g} / \mathrm{L}$, 4 - in relation to $0.25 \mathrm{~g} / \mathrm{L}, 5$ - in relation to $0.3 \mathrm{~g} / \mathrm{L}$

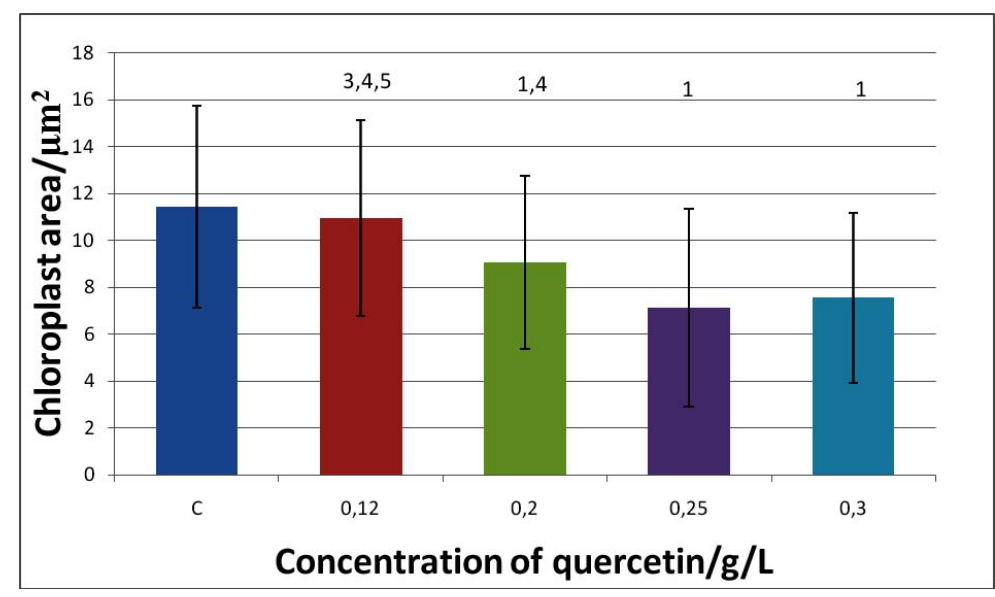

Figure 2. Relationship between the chloroplast area and concentration of quercetin. Vertical lines represent standard deviation. $\mathrm{C}$ - control. Statistically significant $(\mathrm{p}<0.05): 1$ - in relation to $\mathrm{C}, 3$ - in relation to $0.2 \mathrm{~g} / \mathrm{L}$, 4 - in relation to $0.25 \mathrm{~g} / \mathrm{L}, 5$ - in relation to $0.3 \mathrm{~g} / \mathrm{L}$

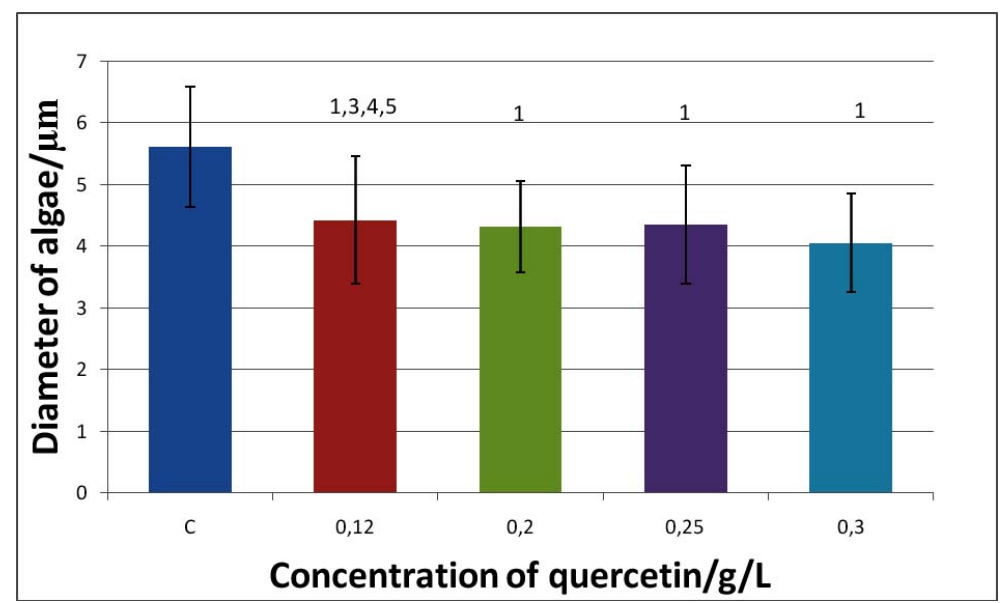

Figure 3. Relationship between the diameter of algae and concentration of quercetin. Vertical lines represent standard deviation. $\mathrm{C}-$ control. Statistically significant $(\mathrm{p}<0.05): 1-$ in relation to $\mathrm{C}, 3$ - in relation to $0.2 \mathrm{~g} / \mathrm{L}$, 4 - in relation to $0.25 \mathrm{~g} / \mathrm{L}, 5$ - in relation to $0.3 \mathrm{~g} / \mathrm{L}$ 


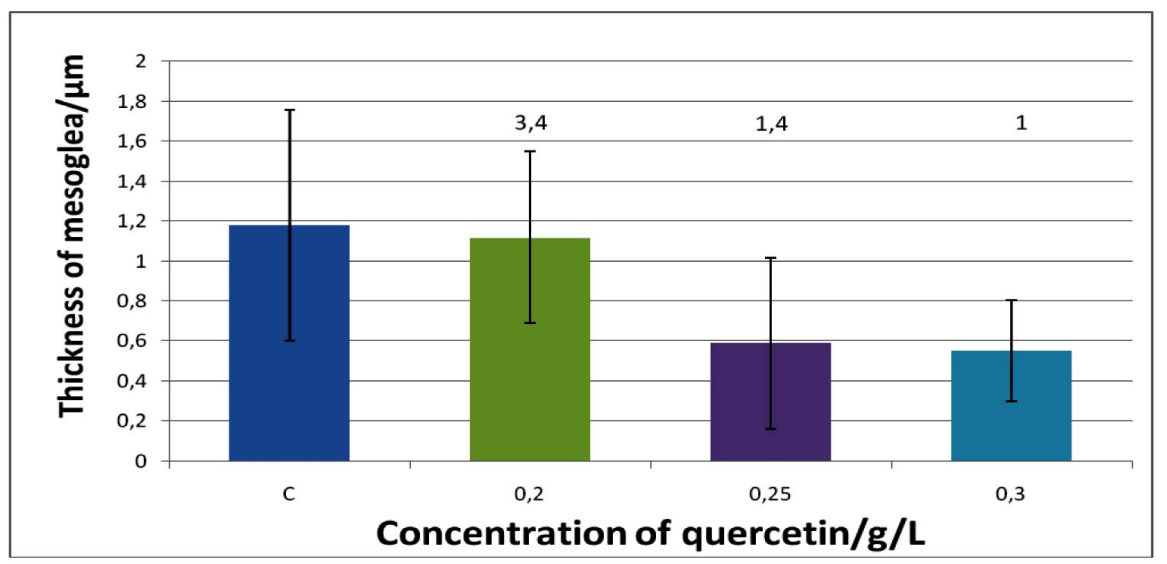

Figure 4. Relationship between the mesoglea thickness and concentration of quercetin. Vertical lines represent standard deviation. $\mathrm{C}$ - control. Statistically significant $(\mathrm{p}<0.05): 1$ - in relation to $\mathrm{C}, 3$ - in relation to $0.25 \mathrm{~g} / \mathrm{L}$, 4 - in relation to $0.3 \mathrm{~g} / \mathrm{L}$

Quercetin showed a deleterious effect on the green hydra and its endosymbiotic alga. Our results showed pro-oxidative processes in the green hydra in response to different concentrations of quercetin. The pro-oxidative effects increased with elevated concentrations of quercetin.

\section{Acknowledgements}

The presented results are a product of the scientific project "Molecular phylogeny, evolution and symbiosis of freshwater invertebrates" carried out with the support of the Ministry of Science, Education and Sport of the Republic of Croatia. The authors would like to thank Dr. Sc. Gordana Gregorović for advice and technical support and Ms Nadica Vincek for technical support.

\section{References}

Agostinucci, K., Manfredi, T. G., Cosmos, A., Martin, K., Han, S. N., Wu, D., ... Meydani, M. (2002). Vitamin $\mathrm{E}$ and age alter liver mitochondrial morphometry. Journal of Anti-Aging Med., 5, 173-178. http://dx.doi.org/10.1089/10945450260195612

Arkhipchuk, W., Blaise, C., \& Malinovskaya, M. V. (2005). Use of hydra for chronic toxicity assessment of waters intended for human consumption. Environmental Pollution, 142, 200-211. http://dx.doi.org/10.1016/j.envpol.2005.10.012

Baker, M. E. (1995). Endocrine activity of plant derived compounds: an evolutionary perspective. Proceedings of the Society for Experimental Biology and Medicine, 208, 131-138.

Beach, M. J., \& Pascoe, D. (1998). The role of Hydra vulgaris (Pallas) in assessing the toxicity of freshwater pollutants. Water Research, 32, 101-106. http://dx.doi.org/10.1016/S0043-1354(97)00180-2

Breslin-Spangenerg, D., \& Eakin, R. E. (1962). Histological studies of mechanisms involved in hydra regeneration. Journal of Experimental Zoology, 151, 85-94. http://dx.doi.org/10.1002/jez.1401510108

Burnett, A. L. (1973). Biology of hydra. New York and London: Academic Press.

Cotelle, N. (2001). Role of flavonoids in oxidative stress. Current Topics in Medicinal Chemistry, 1, 569-590. http://dx.doi.org/10.2174/1568026013394750

De Groot, H. (1994). Reactive oxygen species in tissue injury. Hepatogastroentrology, 41, 32-328.

De Groot, H., \& Rauen, U. (1998). Tissue injury by reactive oxygen species and the protective effects of $\begin{array}{llll}\text { flavonoids. Fundamental } \& \text { Clinical Pharmacology, } & 12,\end{array}$ http://dx.doi.org/10.1111/j.1472-8206.1998.tb00951.x

Ebringer, L., \& Krajčovič, J. (1994). Cell origin and evolution. Bratislava: Publishing House VEDA.

Formica, J. V., \& Regelson, W. (1995). Review of the biology of quercetin and related bioflavonoids. Food and Chemical Toxicology, 33, 80-1061. http://dx.doi.org/10.1016/0278-6915(95)00077-1

Grace, P. A. (1994). Ischemia-reperfusion injury. British Journal of Surgery, 81, 637-47. 
Holstein, T., \& Emschermann, P. (1995). Cnidaria: Hydrozoa, Kamptozoa. Stuttgart: Gustav Fischer Verlag.

Kalafatić, M. (1995). Regeneration of hypostome and foot of hydras treated with Gamacide 20. Biologia Bratislava, 50, 283-287.

Kalafatić, M., \& Kopjar, N. (1994). Response of Green Hydra to the Treatment with Different Pesticides under Laboratory Conditions. Zeitschrift für Angewandte Zoologie, 2, 213-223.

Kalafatić, M., Kovačević, G., Ljubešić, N., \& Šunjić, H. (2001). Effects of ciprofloxacin on green hydra and endosymbiotic alga. Periodicum biologorum, 103, 267-272.

Kovačević, G., Gregorović, G., Kalafatić, M., \& Jaklinović, I. (2009). The Effect of Aluminium on the Planarian Polycelis felina (Daly.). Water, Air and Soil Pollution, 196, 333-344. http://dx.doi.org/10.1007/s11270-008-9781-1

Kovačević, G., Kalafatić, M., Ljubešić, N., \& Šunjić, H. (2001). The effect of chloramphenicol on symbiosis between algae and hydra. Biologia Bratislava, 56, 605-610.

Kovačević, G., Želježić, G., Kalafatić, M., \& Horvatin, K. (2007). Morphological features and comet assay of green and brown hydra treated with aluminium. Symbiosis, 44, 145-152.

Lee, J. C., Kim, J., Park, J. K., Chung, G. H., \& Jang, Y. S. (2003). The antioxidant, rather than prooxidant, activities of quercetin on normal cells: quercetin protects mouse thymocytes from glucose oxidase-mediated apoptosis. Experimental Cell Research, 291, 386-397. http://dx.doi.org/10.1016/S0014-4827(03)00410-5

Maggiolini, M., Bonofiglio, D., Marsico, S., Panno, M. L., Cenni, B., Picard, D., \& Ando, S. (2001). Estrogen receptor alpha mediates the proliferative but not the cytotoxic dose-dependent effects of two major phytoestrogen on human breast cancer cells. Pharmacol, 60, 595-602.

Pool. R. R. Jr., \& Muscatine, L. (1980). Phagocytic recognition and the establishment of the Hydra viridis-Chlorella symbiosis. In W. Schwemmler \& H. E. A. Schenk (Eds.), Endocytobiology. Endosymbiosis and Cell Biology. Vol. I. A Synthesis of Recent Research (pp. 223-238). Berlin, New York: WdeG.

Rajević, N., Matković, H., Gregorović, G., Kovačević, G., Knezović, L., \& Kalafatić M. (2013) Behavioral, Morphological and Histopathological Effects of Sublethal Doses of Quercetin on the Species Polycelis felina (Dalyell). Folia biologica (Kraków), 61(1-2), 101-106. http://dx.doi.org/10.3409/fb61_1-2.101

Sirovina, D., Oršolić, N., Končić, M. Z., Kovačević, G., Benković, V., \& Gregorović G. (2013) Quercetin vs chrysin: Effect on liver histopathology in diabetic mice. Human and Experimental Toxicology. http://dx.doi.org/10.1177/0960327112472993

Wilson, R. W., Bergman, H. L., \& Wood, C. M. (1994). Metabolic costs and physiological consequences of acclimation to aluminum in juvenile rainbow trout (Oncorhynchus mykkis). 1. Acclimation specificity, resting physiology, feeding, and growth. Canadian Journal of Fisheries and Aquatic Science, 51, 527-535. http://dx.doi.org/10.1139/f94-055 